www.jmscr.igmpublication.org

Impact Factor 5.84

Index Copernicus Value: 83.27

ISSN (e)-2347-176x ISSN (p) 2455-0450

crossref DOI: _https://dx.doi.org/10.18535/jmscr/v5i7.45

Journal Of Medical Science And Clinical Research

\title{
A Comprehensive Study of Cervical Lymphadenopathy with special reference to FNAC as a diagnostic Criteria
}

\author{
Authors \\ Siba Prasad Dash ${ }^{1}$, Sulata Choudhury ${ }^{2}$ \\ ${ }^{1}$ Associate Professor, Department of Surgery \\ ${ }^{2}$ Assistant Professor, Department of Pathology \\ M.K.C.G. Medical College \& Hospital, Berhampur-760004, Odisha \\ Corresponding Author \\ Dr Sulata Choudhury \\ C/o. Dr.Siba Prasad Dash \\ Lingaraj Nagar, Near New Bus Stand, BERHAMPUR-760001, Odisha \\ Cell 7978625834, Email: drsibapdash@gmail.com
}

\begin{abstract}
Cervical lymphadenopathy is a common clinical problem. This study was carried out in 50 cases without any consideration to age, FNAC was used to evaluate these patients, biopsy was done only in doubtful cases, in patients with lymphoma and in those with supraclavicular group involvement. Tuberculosis was seen most commonly in the age group of 11-20 years. The male:female ratio was 1:2.5 in tubercular lymphadenopathy. Accuracy rate of FNAC in this series as a whole is $96 \%$. Lymphoma cases were seen in the age group of 3140 years where as metastatic carcinoma was present in patients over 40 years. Matted lymph nodes were seen in $61.9 \%$ cases of tubercular lymphadenitis.

Keywords: Tuberculosis, cervical lymphadenopathy, fine needle aspiration cytology (FNAC).
\end{abstract}

\section{Introduction}

Lymph node enlargement is a very common problem. The commonest site is the enlargement of cervical nodes and the commonest cause of swelling in neck is lymphadenopathy ${ }^{1,12}$. The cause of cervical lymphadenopathy may be due to tuberculosis, chronic lymphadenitis, lymphoma or metastatic carcinoma.

This study was undertaken with an aim to find out the different causes of cervical lymphadenopathy and accuracy of FNAC in diagnosis of cervical lymphadenopathy, without any consideration of age and sex. In only doubtful cases, in patients with lymphoma, in supraclavicular group involvement, and in patients whose symptoms are not alleviated by therapy based on findings of FNAC after a period of 8 weeks were subjected to open biopsy.

\section{Materials and Methods}

This is a prospective study of 50 patients who attended the Surgery Outpatient Department of M.K.C.G. Medical College Hospital, Berhampur between the period of February, 2016 to January 2017. It includes patients with cervical lymphadenopathy of more than 4 weeks duration. 
A detailed history was taken from each, patient regarding the duration of symptoms and the progress of theprocess. Any history of fever, cough, weight loss, anorexia, contact with tubercular person or previous history of tuberculosis was also noted.

All cases were examined with particular reference to site, surface, consistency, periadenitis, fixity to deeper structures and drainage area of the corresponding lymph nodes. A thorough examination of the scalp, oral cavity, indirect laryngoscopy and examination of ear was done. A per abdomen examination, and examination of genetalia was also done. A complete blood count, chest radiograph, mantoux test, were done in all cases. The diagnosis was confirmed by FNAC. When the first FNAC was inconclusive it was repeated for the second time. If the result was still inconclusive excision biopsy was done. The data thus collected was analysed for the various causes of lymphadenopathy, their age and sex distribution, character of the involved lymph nodes and the various groups involved.

\section{Observation}

Table-I Age Incidence

\begin{tabular}{|l|c|c|c|c|c|}
\hline Age in Yrs. & $\begin{array}{c}\text { TB Lympha- } \\
\text { denopathy }\end{array}$ & $\begin{array}{c}\text { Non-specific } \\
\text { reactive } \\
\text { Hyperplasia }\end{array}$ & Lymphomas & $\begin{array}{c}\text { Metastatic } \\
\text { Carcinoma }\end{array}$ & Total \\
\hline $0-10$ & 1 & 0 & 0 & 0 & 1 \\
\hline $11-20$ & 9 & 1 & 0 & 0 & 10 \\
\hline $21-30$ & 4 & 2 & 3 & 1 & 10 \\
\hline $31-40$ & 5 & 3 & 4 & 1 & 13 \\
\hline$>40$ & 2 & 0 & 4 & 10 & 16 \\
\hline
\end{tabular}

Table-II Sex incidence

\begin{tabular}{|l|c|c|c|c|c|}
\hline \multirow{2}{*}{ Diseases } & \multicolumn{2}{|c|}{ Male } & \multicolumn{2}{c|}{ Female } & \multirow{2}{*}{ Total } \\
\cline { 2 - 5 } & No. & $\%$ & No. & $\%$ & \\
\hline TB Lymphadenopathy & 6 & 28.6 & 15 & 71.4 & 21 \\
\hline Non-specific reactive hyperplasia & 2 & 33.3 & 4 & 66.7 & 6 \\
\hline Lymphomas & 4 & 36.4 & 7 & 63.6 & 11 \\
\hline Metastatic Carcinoma & 7 & 58.3 & 5 & 41.7 & 12 \\
\hline Total & 19 & 38 & 31 & 62 & 50 \\
\hline
\end{tabular}

Table-Ill Character of enlarged lymph node

\begin{tabular}{|l|c|c|c|c|}
\hline $\begin{array}{l}\text { Character of lymph } \\
\text { node }\end{array}$ & $\begin{array}{c}\text { Tuberculous } \\
\text { Lymphadenitis }\end{array}$ & $\begin{array}{c}\text { Non-specific } \\
\text { hyperplasia }\end{array}$ & Lymphoma & $\begin{array}{c}\text { Metastatic } \\
\text { carcinoma }\end{array}$ \\
\hline Discrete & 8 & 6 & 8 & 12 \\
\hline Matted & 13 & 0 & 3 & 0 \\
\hline Sinus formation & 0 & 0 & 0 & 0 \\
\hline
\end{tabular}

Table-IV Accuracy of FNAC in the individual groups of lymphadenopathies

\begin{tabular}{|c|c|c|c|c|c|c|}
\hline \multirow{3}{*}{ FNAC } & \multirow{3}{*}{$\begin{array}{l}\text { No. of } \\
\text { Cases }\end{array}$} & \multicolumn{5}{|c|}{ Based on H/P Examination } \\
\hline & & \multicolumn{2}{|c|}{ False Positive } & \multicolumn{2}{|c|}{ False Negative } & \multirow{2}{*}{ Accuracy $\%$} \\
\hline & & No. & $\%$ & No. & $\%$ & \\
\hline TB Lymphadenopathy & 19 & 0 & 0 & 2 & 9.5 & 90.5 \\
\hline Reactive hyperplasia & 7 & 1 & 16.6 & - & - & 83.4 \\
\hline Hodgkin's lymphoma & 5 & - & - & - & - & 100 \\
\hline Non-Hodgkin's lymphoma & 6 & - & - & - & - & 100 \\
\hline Metastatic carcinoma & 12 & - & - & - & - & 100 \\
\hline Inconclusive & 1 & $\ldots$ & - & - & - & - \\
\hline Total & 50 & 1 & 2 & 2 & 4 & 96.0 \\
\hline
\end{tabular}




\section{Results}

In this series, 50 patients presented with chronic cervical lymphadenopathy. The various causes of cervical lymphadenitis and age incidence is shown in Table-I. Tuberculous lymphadenitis is the most common cause of cervical lymphadenopathy and is seen commonly in 2 nd decade of life ${ }^{(11-20)}$. The sex distribution is shown in Table-I I. There were 31 females and 19 males. $71.4 \%$ of female and $28.6 \%$ of males were found to have tubercular lymphadenopathy. FNAC was able to establish the diagnosis in 48 of the cases and biopsy was needed in only 2 cases that is in one case of false positive reactive hyperplasia and in one case where FNAC report was inconclusive. $61.9 \%$ of tubercular lymph nodes were matted where as in case of lymphoma $27.3 \%$ of nodes were matted.

\section{Discussion}

In this study tuberculosis was found to be most common cause of cervical lymphadenopathy $42 \%$ Gupta et $\mathrm{al}^{2}$ found that in their 101 cases of cervical lymphadenopathy $50 \%$ had tuberculosis, a similar result was obtained by Jhawer et $\mathrm{al}^{3}$ in their study, $64 \%$ of their 359 patients had tuberculosis. We found a female preponderance with an M:F ratio to be $1: 2.5$. This is in accordance with Dandapatetal ${ }^{4}$. Maximum incidence of tubercular cervical lymphadenopathy was in the age group of 11-20 years which corresponds to the findings of Trivedi $\&$ BasuMallick $^{5}$ and Pamraetal ${ }^{6}$. The percentage of matted nodes in this series was $61.9 \%$. Seth etal ${ }^{7}$ found matted nodes in $77 \%$ of tubercular lymphadenitis. In this study we have taken help of FNAC as diagnostic criteria, out of 50 cases FNAC could establish diagnosis in $96 \%$ of cases. Sardaetal ${ }^{8}$ have obtained similar results in $97.5 \%$ of the patients. Therefore we would like to suggest that today with increasing role of FNAC it forms an important tool to aid in the diagnosis of cervical lymphadenopathy.

\section{Conclusion}

We conclude that tuberculosis is the most common cause of cervical lymphadenopathy ${ }^{9}$. Lymphoma was seen most commonly in patients during 4th decade and metastatic disease in patients greater than 40 years. The most common age group for tubercular cervical lymphadenopathy was $11-20$ years $^{10}$. FNAC is an easy, accurate, cost-effective, relatively painless, easily repeatable safe method and a reliable aid todiagnosis ${ }^{11}$.

\section{References}

1. Browse NL. An Introduction to the symptoms and signs of surgical disease 3rd ED. London, 1997 PP. 256-257.

2. Gupta AK, Gupta SC, Singh DR et al Lymphadenopathy (A clinic-pathological evaluation) Ind. J. Of Surg. 1988; 50(7): 239-244.

3. JhawerPK, Barat D, Begani MM, Chronic cervical Lymphadenopathy -A rational approach to its management. Indian J. Surg. 1990; 52: 25-30.

4. Dandapat MC, Mishra BM, Dash SP et al: Peripheral Lymph node tuberculosis: A review of 80 cases: Br.J. Surg 1990 August: 77 (8): 911-2.

5. Trivedi BP, Basumallick KC; Lymph node Biopsy. Ind. J. Surg. 1953: 15:74.

6. PamraSP, Mathur GP, A cooperative study of Tuberculosis cervical lymphadenopathy Ind. J. M.Res. 1974; 62: 1631-1646.

7. Seth V, Kabra SK, Jain Y, et al : Tubercular Lymphadenitis: Clinical Manifestation: Indian J. Paediatrics 1995 September-October 62(5): 565-70.

8. Sarda AK, Bal S Singh MK et al: Fine needle aspiration cytology as a preliminary diagnostic procedure for asymptomatic cervical lymphadenopathy. JAPI., 1990 March 38(3): 203-205.

9. Ochicha O, Edino ST, Mohammed AZ, Umar AB, Atanda AT. Pathology of peripheral lymph node biopsies in Kano, 
Northern Nigeria. Annals of African medicine. 2007 Sep $1 ; 6(3): 104$.

10. Subrahmanyam M. Role of surgery and chemotherapy for peripheral lymph node tuberculosis. British journal of surgery. 1993 Dec 1;80(12):1547-8.

11. Olu-Eddo AN, Omoti CE. Diagnostic evaluation of primary cervical adenopathies in a developing country. Pan African Medical Journal. $2011 ; 10$.

12. Lioe TF, Elliott H, Allen DC, Spence RA. The role of fine needle aspiration cytology (FNAC) in the investigation of superficial lymphadenopathy; uses and limitations of the technique. Cytopathology. 1999 Oct 1;10(5):291-7. 